\title{
The Effect of Erythropoietin on Oviductal Congestion during Ischemia Reperfusion Injury in Rats
}

\author{
Tsompos $\mathrm{C}^{1}$, Panoulis $\mathrm{C}^{2}$, Toutouzas $\mathrm{K}^{3}$, Triantafyllou $\mathrm{A}^{4}$, Zografos $\mathrm{G}^{5}$ and Papalois $\mathrm{A}^{6}$ \\ ${ }^{1}$ Department of Obstetrics \& Gynecology, Mesologi County Hospital, Greece \\ ${ }^{2}$ Department of Obstetrics \& Gynecology, Aretaieion Hospital, Athens University, Greece \\ ${ }^{3}$ Department of Surgery, Athens University, Greece \\ ${ }^{4}$ Department of Biologic Chemistry, Athens University, Greece \\ ${ }^{5}$ Department of Surgery, Athens University, Greece \\ ${ }^{6}$ Experimental Research Centre ELPEN Pharmaceuticals, Attiki, Greece
}

Submission: April 20, 2017; Published: June 09, 2017

*Corresponding author: Tsompos C, Department of Obstetrics \& Gynecology, Mesologi County Hospital, Nafpaktou street, Mesologi 30200, Etoloakarnania, Greece, Tel: 00302631360237/00306946674264; Fax: 00302106811215; Email: Tsomposconstantinos@gmail.com

Abstract

Introduction: This experimental study examined the effect of erythropoietin on a rat model and particularly in an oviductal ischemia reperfusion (IR) protocol. The effects of that molecule were studied pathologically using mean oviductal congestion (OC) lesions. Materials and methods: 40 rats of mean weight $247.7 \mathrm{~g}$ were used in the study. OC lesions were evaluated at $60 \mathrm{~min}$ (groups A and C) and at $120 \mathrm{~min}$ (groups $\mathrm{B}$ and D) of reperfusion. Erythropoietin was administered only in groups C and D. Results: Epo administration significantly decreased the OC scores by 0.3 without lesions [-0.6200848 - 0.0200848$]$ ( $\mathrm{p}=0.0496)$. Reperfusion kept non-significantly increased the OC scores by 0.25 without lesions $[-0.4759001-0.1759001](\mathrm{P}=0.2831)$. Together, the Epo administration and reperfusion time non significantly decreased the OC scores by 0.1090909 without lesions $[-0.3078424-0.0896606](\mathrm{p}=0.2735)$.

Conclusion: Epo administration significantly decreased the OC score lesions in oviducts, however, within the same grade class. A longer study time or a higher Epo dose may reveal more significant results.

Keywords: Ischemia; Erythropoietin; Oviductal congestion; Reperfusion

\section{Introduction}

Erythropoietin (Epo) is generally one of the more well studied growth factors. Epo implicates over 29001 known biomedical studies at present. $3.42 \%$ at least of these studies concern tissue ischemia-reperfusion (IR) experiments. Certainly, important progress has been made concerning the Epo usage in reversing the IR kind of transient or permanent injuries including adjacent organs and certainly patients' health. Nevertheless, satisfactory answers have not been provided yet to basic questions, as, its action velocity, the administration timing and the dosage. The concept is to forward the knowledge away from the original action of Epo in stem blood cells recovery. However, just few related reports were found, not covering completely more specific matters. A numeric evaluation of the Epo efficacy was yielded by a meta-analysis of 31 published seric variables, based on the same experimental setting, at the same endpoints (Table 1). The special aim of this experimental work was to study the effect of Epo on a rat model and mainly in an oviductal IR protocol. The effect of Epo molecule was tested by evaluating the mean oviductal congestion (OC) lesions.

Materials and methods

\section{Animal preparation}

This experimental study was licensed by Veterinary Address of East Attiki Prefecture under 3693/12-11-2010 \& 14/10-12012 decisions. All consumables, equipment and substances, were a courtesy of Experimental Research Centre of ELPEN Pharmaceuticals Co. Inc. S.A. at Pikermi, Attiki. Appropriate humanistic care was adopted for Albino female Wistar rats. Normal housing in laboratory 7 days before the experiment included ad libitum diet. Post-experimental euthanasia did not permit awakening and preservation of the rodents. They were randomly delivered to four experimental groups by 10 animals in each one. Ischemia for $45 \mathrm{~min}$ followed by reperfusion for $60 \mathrm{~min}$ (group A). Ischemia for $45 \mathrm{~min}$ followed by reperfusion for 
$120 \mathrm{~min}$ (group B). Ischemia for $45 \mathrm{~min}$ followed by immediate Epo intravenous (IV) administration and reperfusion for $60 \mathrm{~min}$ (group C). Ischemia for $45 \mathrm{~min}$ followed by immediate Epo IV administration and reperfusion for $120 \mathrm{~min}$ (group D). The molecule Epo dosage was $10 \mathrm{mg} / \mathrm{Kg}$ body weight of animals. Prenarcosis of animals proceeded of nonstop intra-experimental general anesthesia, oxygen supply, electrocardiogram and acidometry [1-6]. The protocol of IR was followed. Ischemia was caused by laparotomic forceps clamping inferior aorta over renal arteries for $45 \mathrm{~min}$. The clamp removal restored the inferior aorta patency and reperfusion. The molecules were administered at the time of reperfusion, through catheterized inferior vena cava. The OC evaluations were performed at $60 \mathrm{~min}$ of reperfusion (for groups A and C) and at 120 min of reperfusion (for groups B and D). The mean weight of the forty (40) female Wistar albino rats used was 247.7g [Standard Deviation (SD): 34.99172g], with min weight $\geq 165 \mathrm{~g}$ and max weight $<320 \mathrm{~g}$. Rats' weight could be potentially a confusing factor, e.g. the more obese rats to have greater OC scores lesions. This assumption was investigated. Also, detailed pathologic [7] study and grading of OC findings was performed by scores, this is: 0 lesions were not found, 1 mild lesion was found, 2 moderate lesions were found and 3 serious lesions were found. The previous grading was transformed as follows: (0-0.499) without lesions, (0.5-1.499) the mild lesions, (1.5-2.499) the moderate lesions and (2.5-3) the serious lesions damage, because the study concerns score ranges rather than point scores. OC scores were measured by $1^{\text {st }}$ Department of Pathology at Department of Clinical-Laboratory studies in Faculty of Medicine of Athens University.

Table 1: The erythropoietin (Epo) influence ( +-SD) on the levels of some seric1 variables concerning reperfusion (rep) time.

\begin{tabular}{|c|c|c|c|c|c|c|c|c|}
\hline Variable & $1 \mathrm{~h}$ rep & p-value & $1.5 \mathrm{~h}$ rep & p-value & $2 \mathrm{~h}$ rep & p-value & $\begin{array}{l}\text { interaction of } \\
\text { Epo and rep }\end{array}$ & p-value \\
\hline White BCC & $+24.01 \% \pm 13.38 \%$ & 0.1012 & $+22.09 \% \pm 9.11 \%$ & 0.0163 & $+20.17 \% \pm 12.94 \%$ & 0.0902 & $+14.63 \% \pm 5.40 \%$ & 0.0080 \\
\hline Red BCC & $+1.45 \% \pm 3.31 \%$ & 0.6589 & $+0.37 \% \pm 3.02 \%$ & 0.9048 & $-0.70 \% \pm 4.68 \%$ & 0.8844 & $+0.81 \% \pm 1.79 \%$ & 0.6446 \\
\hline Hematocrit & $+0.14 \% \pm 2.89 \%$ & 0.9626 & $-0.61 \% \pm 2.37 \%$ & 0.8072 & $-1.37 \% \pm 4.05 \%$ & 0.7485 & $+0.24 \% \pm 1.38 \%$ & 0.8586 \\
\hline $\begin{array}{l}\text { Hemoglobi } \\
{[6]}\end{array}$ & $+4.09 \% \pm 5.20 \%$ & 0.3350 & $+2.15 \% \pm 2.63$ & 0.4527 & $+0.20 \% \pm 5.08 \%$ & 0.9584 & $+1.31 \% \pm 1.59 \%$ & 0.3984 \\
\hline $\mathrm{MCH}$ & $+0.01 \% \pm 1.29 \%$ & 0.9904 & $+0.67 \% \pm 0.80 \%$ & 0.3549 & $+1.34 \% \pm 1.08 \%$ & 0.1509 & $-0.36 \% \pm 0.47 \%$ & 0.4430 \\
\hline MCV [5] & $+0.01 \% \pm 1.08 \%$ & 0.9904 & $+0.56 \% \pm 0.66 \%$ & 0.3549 & $+1.12 \% \pm 0.91 \%$ & 0.1509 & $+0.30 \% \pm 0.39 \%$ & 0.4430 \\
\hline MCHC [3] & $+1.82 \% \pm 0.56 \%$ & 0.0076 & $+1.73 \% \pm 0.50 \%$ & 0.0016 & $+1.65 \% \pm 0.92 \%$ & 0.0721 & $+0.89 \% \pm 0.31 \%$ & 0.0061 \\
\hline RbcDW & $-1.85 \% \pm 4.24 \%$ & 0.6703 & $-1.64 \% \pm 2.53 \%$ & 0.5159 & $-1.43 \% \pm 3.34 \%$ & 0.6078 & $-1.06 \% \pm 1.43 \%$ & 0.4733 \\
\hline Plt C [2] & $-7.32 \% \pm 13.11 \%$ & 0.5219 & $-2.14 \% \pm 8.04 \%$ & 0.7581 & $+3.04 \% \pm 10.78 \%$ & 0.7204 & $-0.16 \% \pm 4.76 \%$ & 0.9725 \\
\hline Platelet DW & $+1.60 \% \pm 0.80 \%$ & 0.0765 & $+1.36 \% \pm 0.58 \%$ & 0.0205 & $+1.13 \% \pm 0.74 \%$ & 0.1152 & $+0.37 \% \pm 0.37 \%$ & 0.0615 \\
\hline Platelet-crit & $-16.47 \% \pm 10.40 \%$ & 0.0921 & $-13.74 \% \pm 7.01 \%$ & 0.0158 & $-11.01 \% \pm 7.34 \%$ & 0.0882 & $-6.88 \% \pm 3.69 \%$ & 0.0615 \\
\hline Urea & $+21.42 \% \pm 7.84 \%$ & 0.0115 & $+20.11 \% \pm 7.25 \%$ & 0.0059 & $+18.80 \% \pm 9.44 \%$ & 0.0709 & $+15.64 \% \pm 4.04 \%$ & 0.0003 \\
\hline Creatinine & $-0.10 \% \pm 9.78 \%$ & 0.9904 & $-4.84 \% \pm 5.78 \%$ & 0.3721 & $-9.59 \% \pm 7.74 \%$ & 0.1509 & $-2.62 \% \pm 3.49 \%$ & 0.4430 \\
\hline Uric acid & $+10.13 \% \pm 15.10 \%$ & 0.4917 & $+15.86 \% \pm 10.21 \%$ & 0.1408 & $+21.59 \% \pm 15.45 \%$ & 0.1940 & $+9.33 \% \pm 6.16 \%$ & 0.1264 \\
\hline Total protei & $-0.02 \% \pm 2.47 \%$ & 904 & $-1.27 \% \pm 1.51 \%$ & $\angle 1$ & $-2.52 \% \pm 2.03 \%$ & 0.1509 & $-0.68 \% \pm 2.48 \%$ & 0.4430 \\
\hline Albumins & $-4.61 \% \pm 4.21 \%$ & 0.2530 & $-9.28 \% \pm 3.20 \%$ & 0.0054 & $-13.96 \% \pm 5.03 \%$ & 0.0095 & $-5.37 \% \pm 2.73 \%$ & 0.0072 \\
\hline ALT & $+18.89 \% \pm 12.42 \%$ & 0.1372 & $+7.63 \% \pm 18.94 \%$ & 0.6396 & $-3.63 \% \pm 25.19 \%$ & 0.8617 & $+8.03 \% \pm 11.36 \%$ & 0.4698 \\
\hline AST & $+29.53 \% \pm 9.72 \%$ & 0.0096 & $+26.71 \% \pm 13.17 \%$ & 0.0235 & $+23.89 \% \pm 21.59 \%$ & 0.1709 & $+19.73 \% \pm 7.70 \%$ & 0.0119 \\
\hline$\gamma \mathrm{GT}$ & $-19.35 \% \pm 18.58 \%$ & 0.2362 & $-12.70 \% \pm 13.11 \%$ & 0.3541 & $-6.06 \% \pm 19.96 \%$ & 0.7800 & $-4.62 \% \pm 7.97 \%$ & 0.5534 \\
\hline ALP & $+0.20 \% \pm 18.57 \%$ & 0.9904 & $+10.70 \% \pm 12.78 \%$ & 0.3549 & $+21.20 \% \pm 17.11 \%$ & 0.1509 & $+5.79 \% \pm 7.72 \%$ & 0.4430 \\
\hline ACP & $+0.06 \% \pm 5.79 \%$ & 0.9904 & $+3.11 \% \pm 3.71 \%$ & 0.3172 & $+6.16 \% \pm 4.97 \%$ & 0.1509 & $+1.68 \% \pm 2.23 \%$ & 0.4430 \\
\hline $\mathrm{CPK}$ & $+0.15 \% \pm 14.09 \%$ & 0.9904 & $+7.91 \% \pm 9.44 \%$ & 0.3549 & $+15.67 \% \pm 12.65 \%$ & 0.1509 & $+4.28 \% \pm 5.70 \%$ & 0.4430 \\
\hline CK-MB [4] & $+0.08 \% \pm 7.90 \%$ & 0.9904 & $+4.28 \% \pm 5.11 \%$ & 0.3721 & $+8.49 \% \pm 6.85 \%$ & 0.1509 & $+2.32 \% \pm 3.09 \%$ & 0.4430 \\
\hline LDH & $+0.08 \% \pm 7.92 \%$ & 0.9904 & $+4.48 \% \pm 5.35 \%$ & 0.3549 & $+8.89 \% \pm 7.17 \%$ & 0.1509 & $+2.42 \% \pm 3.22 \%$ & 0.4430 \\
\hline Sodium & $+0.72 \% \pm 0.74 \%$ & 0.3054 & $+0.21 \% \pm 0.63 \%$ & 0.7136 & $-0.29 \% \pm 1.09 \%$ & 0.7670 & $-0.11 \% \pm 0.38 \%$ & 0.7531 \\
\hline Potassium & $-6.17 \% \pm 4.94 \%$ & 0.1540 & $-2.21 \% \pm 3.66 \%$ & 0.5134 & $+1.74 \% \pm 5.43 \%$ & 0.7299 & $+0.18 \% \pm 2.22 \%$ & 0.9338 \\
\hline
\end{tabular}


Juniper Online Journal Material Science

\begin{tabular}{|c|c|c|c|c|c|c|c|c|}
\hline Calcium & $0.28 \% \pm 1.19 \%$ & 0.8065 & $-0.56 \% \pm 1.13 \%$ & 0.5761 & $-1.41 \% \pm 2.08 \%$ & 0.4100 & $-0.34 \% \pm 0.68 \%$ & 0.6095 \\
\hline Phosphorus & $+1.92 \% \pm 5.25 \%$ & 0.6982 & $+3.95 \% \pm 3.35 \%$ & 0.2100 & $+5.98 \% \pm 4.81 \%$ & 0.2930 & $+2.45 \% \pm 2.01 \%$ & 0.2168 \\
\hline Magnesium & $+1 \% \pm 6.20 \%$ & 0.8596 & $-1.09 \% \pm 3.34 \%$ & 0.7248 & $-3.19 \% \pm 3.90 \%$ & 0.3729 & $-0.19 \% \pm 1.93 \%$ & 0.9197 \\
\hline Amylase & $+6.50 \% \pm 9.15 \%$ & 0.4161 & $+5.04 \% \pm 6.12 \%$ & 0.3831 & $+3.59 \% \pm 8.42 \%$ & 0.6649 & $+4.36 \% \pm 3.65 \%$ & 0.2258 \\
\hline Progesteron & $-0.20 \% \pm 18.65 \%$ & 0.9904 & $-8.86 \% \pm 10.58 \%$ & 0.3549 & $-17.53 \% \pm 14.15 \%$ & 0.1509 & $-4.79 \% \pm 6.39 \%$ & 0.4430 \\
\hline Mean & $+2.20 \% \pm 10.08 \%$ & 0.5712 & $+2.58 \% \pm 9.20 \%$ & 0.3660 & $+2.96 \% \pm 10.43 \%$ & 0.3586 & $+2.18 \% \pm 5.98 \%$ & 0.4110 \\
\hline
\end{tabular}

\section{Model of ischemia-reperfusion injury}

Control groups: 20 control rats (mean mass 252.5g [SD: 39.31988g]) experienced ischemia for $45 \mathrm{~min}$ followed by reperfusion.

Table 2: Weight and oviductal congestion (OC) score mean levels and Std. Dev. of groups.

\begin{tabular}{|c|c|c|c|}
\multicolumn{1}{c}{ Groups } & \multicolumn{1}{c}{ Variable } & \multicolumn{1}{c|}{ Mean } & Std. Dev \\
\hline A & Weight & $243 \mathrm{~g}$ & $45.77724 \mathrm{~g}$ \\
\hline & OC & mild 0.5 & 0.5270463 \\
\hline B & Weight & $262 \mathrm{~g}$ & $31.10913 \mathrm{~g}$ \\
\hline & OC & without lesions 0.4 & 0.6992059 \\
\hline C & Weight & $242.8 \mathrm{~g}$ & $29.33636 \mathrm{~g}$ \\
\hline & OC & without lesions 0 & 0 \\
\hline D & Weight & $243 \mathrm{~g}$ & $32.84644 \mathrm{~g}$ \\
\hline & OC & without lesions 0.3 & 0.4830459 \\
\hline
\end{tabular}

Group A: Reperfusion lasted for $60 \mathrm{~min}$ ( $\mathrm{n}=10$ controls rats) mean mass $243 \mathrm{~g}$ [SD: $45.77724 \mathrm{~g}$ ], mean mild OC score 0.5 [SD: 0.5270463] (Table 2).

Group B: Reperfusion lasted for $120 \mathrm{~min}$ ( $\mathrm{n}=10$ controls rats) mean mass 262g [SD: $31.10913 \mathrm{~g}$ ], mean without lesions

Erythropoietin group: 20 Epo rats (mean mass 242.9g [SD: $30.3105 \mathrm{~g}$ ] experienced ischemia for $45 \mathrm{~min}$ followed by reperfusion in the beginning of which $10 \mathrm{mg}$ Epo/kg body weight were IV administered.

Group C: Reperfusion lasted for 60min (n=10 Epo rats) mean mass 242.8g [SD: $29.33636 \mathrm{~g}$ ], mean without OC score 0 [SD: 0] (Table 2).

Group D: Reperfusion lasted for $120 \mathrm{~min}$ (n=10 Epo rats) mean mass 243g [SD: $32.84644 \mathrm{~g}$ ], mean without lesions OC score 0.3 [SD: 0.4830459] (Table 2).

\section{Statistical analysis}

Table 3: Statistical significance of mean values difference for groups (DG) after statistical standard t test application for weight and Wilcoxon signed-rank test for scores.

\begin{tabular}{|c|c|c|c|}
\hline DG & Variable & Difference & p-value \\
\hline A-B & Weight & $-19 \mathrm{~g}$ & 0.2423 \\
\hline & OC & without lesions 0.1 & 0.7055 \\
\hline A-C & Weight & $0.2 \mathrm{~g}$ & 0.9900 \\
\hline & OC & mild 0.5 & 0.0253 \\
\hline A-D & Weight & 0g & 1.0000 \\
\hline & OC & without lesions 0.2 & 0.3173 \\
\hline
\end{tabular}

\begin{tabular}{|c|c|c|c|}
\hline B-C & Weight & $19.2 \mathrm{~g}$ & 0.2598 \\
\hline & OC & without lesions 0.4 & 0.0842 \\
\hline B-D & Weight & $19 \mathrm{~g}$ & 0.1011 \\
\hline & OC & without lesions 0.1 & 0.5637 \\
\hline C-D & Weight & $-0.2 \mathrm{~g}$ & 0.9883 \\
\hline & OC & without lesions - 0.3 & 0.0833 \\
\hline
\end{tabular}

Every weight and OC lesions score group was compared with each other from 3 remained groups applying statistical standard t-tests and Wilcoxon signed-rank tests respectively (Table 3). If any probable significant difference among OC lesions score was raised, it would be investigated whether owed in any respective probable significant mass one (Table 3). Then, the application of generalized linear models ( $\mathrm{glm}$ ) was followed. It included as dependant variable the OC lesions scores. The 3 independent variables were the Epo administration or no, the reperfusion time and their interaction. Inserting the rats' weight as independent variable at glm, a non significant relation turned on with OC scores lesions ( $p=0.0585)$, so as to further investigation was not needed. The statistical analysis was performed by Stata 6.0 software [Stata 6.0, StataCorp LP, Texas, USA] [5].

\section{Results}

The glm resulted in: Epo administration significantly decreased the OC scores by $0.3[-0.6200848-0.0200848](\mathrm{p}=$ 0.0654). This finding was crepant with the results of Wilcoxon signed-rank test $(p=0.0339)$. Reperfusion time kept nonsignificantly increased the OC scores by 0.1 [-0.2332897 0.4332897] ( $\mathrm{P}=0.5472$ ), approximately in accordance with the Wilcoxon signed-rank test result increased by $0.4[-0.7185105$ - -0.0814895] $(\mathrm{P}=0.0190)$. However, Epo administration and reperfusion time in combination non-significantly decreased the OC scores by 0.1090909 [-0.3078424 - 0.0896606] ( $p=0.2735)$. The above and Table 3 are summed in Tables 4 \& 5 [6,7].

Table 4: The decreasing influence of erythropoietin in connection with reperfusion time.

\begin{tabular}{|c|c|c|c|c|}
\hline Decrease & $\mathbf{9 5 \%}$ c. in. & $\begin{array}{c}\text { p-values } \\
\text { Reperfusion } \\
\text { time }\end{array}$ & Wilcoxon & glm \\
\hline mild 0.5 & $\begin{array}{c}-0.850153- \\
0.1498463\end{array}$ & $1 \mathrm{~h}$ & 0.0253 & 0.0077 \\
\hline $\begin{array}{c}\text { without } \\
\text { lesions 0.3 }\end{array}$ & $\begin{array}{c}-0.6200848- \\
0.0200848\end{array}$ & $1.5 \mathrm{~h}$ & 0.0339 & 0.0654 \\
\hline $\begin{array}{c}\text { without } \\
\text { lesions 0.1 }\end{array}$ & $\begin{array}{c}-0.6646058- \\
0.4646058\end{array}$ & $2 \mathrm{~h}$ & 0.5637 & 0.7142 \\
\hline
\end{tabular}




\section{Juniper Online Journal Material Science}

\begin{tabular}{|c|c|c|c|c|}
\hline $\begin{array}{c}\text { without } \\
\text { lesions -0.1 }\end{array}$ & $\begin{array}{c}-0.2332897- \\
0.4332897\end{array}$ & $\begin{array}{c}\text { reperfusion } \\
\text { time }\end{array}$ & & 0.5472 \\
\hline $\begin{array}{c}\text { without } \\
\text { lesions -0.4 }\end{array}$ & $\begin{array}{c}-0.7185105 \\
-0.0814895\end{array}$ & $\begin{array}{c}\text { reperfusion } \\
\text { time }\end{array}$ & 0.0190 & \\
\hline $\begin{array}{c}\text { Without } \\
\text { lesions } \\
0.1090909\end{array}$ & $\begin{array}{c}-0.3078424- \\
0.0896606\end{array}$ & interaction & & 0.2735 \\
\hline
\end{tabular}

Table 5: Consice presence of the decreasing influence of erythropoietin in connection with reperfusion time.

\begin{tabular}{|c|c|c|c|}
\hline Decrease & $95 \%$ C. In. & $\begin{array}{c}\text { Reperfusion } \\
\text { Time }\end{array}$ & P-Values \\
\hline mild 0.5 & $\begin{array}{l}-0.8501537 \\
-0.1498463\end{array}$ & $1 \mathrm{~h}$ & 0.0165 \\
\hline without lesions 0.3 & $\begin{array}{c}-0.6200848- \\
0.0200848\end{array}$ & $1.5 \mathrm{~h}$ & 0.0496 \\
\hline without lesions 0.1 & $\begin{array}{c}-0.6646058- \\
0.4646058\end{array}$ & $2 \mathrm{~h}$ & 0.6389 \\
\hline without lesions -0.25 & $\begin{array}{c}-0.4759001- \\
0.1759001\end{array}$ & $\begin{array}{l}\text { reperfusion } \\
\text { time }\end{array}$ & 0.2831 \\
\hline without lesions 0.1090909 & $\begin{array}{c}-0.3078424- \\
0.0896606\end{array}$ & interaction & 0.2735 \\
\hline
\end{tabular}

\section{Discussion}

The following situations show the association between ischemia and congestion in oviducts. Ajayi OL et al. [8] observed severe congestion, hyperemia, edema, dilatation and devitalization in the affected portion of an oviductal 360 degrees volvulus clockwise around the dorsal ligament during routine postmortem examination in an 11 months old chicken (Gallus gallus domesticus). Gordts S et al. [9] elucidated the process of human ovum retrieval by fimbriae. The fimbriae on the ovulatory side appeared congested, tumescent and showed pulsatile movements synchronous with the heartbeat. Vascular congestion causing erection and pulsatile movements of the fimbriae play a role in the retrieval of the ovum. Tuffrey $M$ et al. [10] suggested that severe mucus congestion accompanied by tubal edema and loss of ciliated epithelia play a major role in the aetiology of chlamydial-induced tubal damage. Kleinstein J et al. [11] supposed that the oviduct damage caused only by the mechanical influence of the secretion congestion is the reason for the unfavorable pregnancy rate after salpingoneostomy of a chronic atrophied hydrosalpinx.

Thus, congestion is associated with Epo not only in oviducts but also in different tissues. Rashed FK et al. [12] showed short-term protective efficacy of Epo in rat testicular IR injury although vascular congestion [12], edema, hemorrhage and acute inflammation were observed in some groups. McMurray JJ et al. [13] described the long duration heart failure in patients treated by $\alpha$-darbepoetin who had more signs of congestion. Lagarto $A$ et al. [14] showed weak edema and vascular congestion in the right nostril of all control and treated Wistar rats groups, after $15 \mu$ l Epo administration, similar to that produced in the brain during hypoxia. Zheng L et al. [15] might improve aortic stenosis induced pulmonary congestion in patients treating pre-operative aortic valve replacement with rhEpo in a mouse model. Piloto $\mathrm{N}$ et al. [16] supposed heart failure as sudden death cause in died rat's tissues presented [16] with brain vascular congestion. Naito $Y$ et al. [17] investigated the mechanisms of cardiac remodeling induced by 20 weeks iron deficiency anemia promoting lung congestion, with decreased serum Epo concentration. Kiris I et al. [18] showed that Epo significantly decreased the focal glomerular necrosis, dilation of Bowman's capsule, degeneration and necrosis of tubular epithelium, interstitial inflammatory infiltration and congestion of blood vessels induced by aortic IR in rats. Minamishima YA et al. [19] demonstrated premature mortality associated with marked venous congestion in mice lacking enzyme PHD2. Lee TH et al. [20] noted splenomegaly caused by the congestion of red pulp in a mouse model deficient in peroxiredoxins II-/-, although healthy in appearance and fertility. Ruschitzka FT et al. [21] treated polyglobulic transgenic mice over expressing hEpo by NO synthase inhibitor N(G)nitro-L-arginine methyl ester (L-NAME) and revealed acute left ventricular dilatation and vascular engorgement associated with pulmonary congestion. Gentz EJ et al. [22] revealed pulmonary congestion resulting from polycythemia $74 \%$ due to high serum Epo concentration in a llama.

Specially, oviducts and Epo are associated in the following situations. Lappin $\mathrm{T}$ [23] supposed that the beneficial effects of hEpo may extend to organs such as ovaries, oviducts, uterus which has Epo receptors. Sasaki R et al. [24] claimed that Epo is both estrogen inducible and produced in oviducts. Masuda $\mathrm{S}$ et al. [25] found E2 and hypoxia induced, transient, rapidly downregulated stimulation of Epo mRNA in oviductal ampulla and isthmus regions. The $\mathrm{E} 2$ action is probably mediated through the E2 receptor and de novo protein synthesis is not required for E2 induced Epo mRNA. Ochiai $\mathrm{H}$ et al. [26] attained the synthesis of hEpo protein attempting localized in-vivo plasmid DNA gene transfer in laying chicken oviducts.

\section{Conclusion}

Epo administration decreased the OC score lesions in oviducts, however, within the same grade class. A longer study time or a higher Epo dose may reveal more significant results.

\section{Acknowledgment}

This study was funded by Scholarship by the Experimental Research Center ELPEN Pharmaceuticals (E.R.C.E), Athens, Greece. The research facilities for this project were provided by the aforementioned institution.

\section{References}

1. Tsompos C, Panoulis C, Toutouzas K, Triantafyllou A, Zografos G, et al (2016) The Effect of Erythropoietin on Aspartate Aminotransferase Levels during Ischemia Reperfusion Injury in Rats. Electronic Journal of Biology 12(2): 161-167.

2. Tsompos C, Panoulis C, Toutouzas K, Triantafyllou A, Zografos G, et al. (2016) The acute trend of erythropoietin on platelet count during hypoxia reoxygenation injury in rats. Medical Channel Karachi 22(1): 7-13. 
3. Tsompos C, Panoulis C, Toutouzas K, Zografos G, Papalois A (2016) The acute effect of erythropoietin on mean corpuscular hemoglobin concentration levels during hypoxia - reoxygenation injury in rats. J Med Soc 30(2):79-83.

4. Tsompos C, Panoulis C, Toutouzas K, Triantafyllou A, Zografos G, et al. (2015) The effect of erythropoietin on creatine kinase MB levels during hypoxia reoxygenation injury in rats. Research Journal of Pharmacology and Toxicology 1(5): 51-53.

5. Tsompos C, Panoulis C, Toutouzas K, Triantafyllou A, Zografos G, et al (2016) The acute effect of erythropoietin on mean corpuscular volume levels during hypoxia-reoxygenation injury in rats. Journal of Cellular Biotechnology 2(1): 77-83.

6. Tsompos C, Panoulis C, Toutouzas K, Triantafyllou A, Zografos G, et al. (2013) The Short-Term Effect of Erythropoietin on Hemoglobin During Ischemia Reperfusion Injury In Rats. Fiziologia 233(79): 26-32.

7. Osmanağaoğlu MA, Kesim M, Yuluğ E, Menteșe A, Karahan SC (2012) Ovarian-protective effects of clotrimazole on ovarian ischemia/ reperfusion injury in a rat ovarian-torsion model. Gynecol Obstet Invest 74(2): 125-130.

8. Ajayi OL, Antia RE, Omotainse SO (2008) Oviductal volvulus in a Nera black chicken (Gallus gallus domesticus) in Nigeria. Avian Pathol 37(2): 139-140.

9. Gordts S, Campo R, Rombauts L, Brosens I (1998) Endoscopic visualization of the process of fimbrial ovum retrieval in the human. Hum Reprod 13(6): 1425-1428.

10. Tuffrey M, Alexander F, Inman C, Ward ME (1990) Correlation of infertility with altered tubal morphology and function in mice with salpingitis induced by a human genital-tract isolate of Chlamydia trachomatis. J Reprod Fertil 88(1): 295-305.

11. Kleinstein J, Neubüser D, Mussmann J (1982) Mechanically induced tube damage in the artificial hydrosalpinx. Gynecol Obstet Invest 14(4): 292-299.

12. Rashed FK, Ghasemi B, Deldade Mogaddam H, Mesgari M (2013) The effect of erythropoietin on ischemia/reperfusion injury after testicular torsion/detorsion: a randomized experimental study. ISRN Urol 2013: 351309.

13. McMurray JJ, Anand IS, Diaz R, Maggioni AP, O'Connor C, et al. (2013) Baseline characteristics of patients in the Reduction of Events with Darbepoetin alfa in Heart Failure trial (RED-HF). Eur J Heart Fail 15(3): 334-341.

14. Lagarto A, Bueno V, Guerra I, Valdés O, Couret M, et al. (2011) Absence of hematological side effects in acute and subacute nasal dosing of erythropoietin with a low content of sialic acid. Exp Toxicol Pathol 63(6): 563-567.

15. Zheng L, Xu J, Qiu W, Liu X, Zhao CM, et al. (2010) Cardioprotection of exogenous erythropoietin in mice with ligature-induced aortic stenosis: effects on maladaptive cardiac hypertrophy. J Physiol Pharmacol 61(1): 13-20.

16. Piloto N, Teixeira HM, Teixeira-Lemos E, Parada B, Garrido P, et al. (2009) Erythropoietin promotes deleterious cardiovascular effects and mortality risk in a rat model of chronic sports doping. Cardiovasc Toxicol 9(4): 201-210.

17. Naito Y, Tsujino T, Matsumoto M, Sakoda T, Ohyanagi M, et al. (2009) Adaptive response of the heart to long-term anemia induced by iron deficiency. Am J Physiol Heart Circ Physiol 296(3): H585- H593.

18. Kiris I, Kapan S, Kilbas A, Yilmaz N, Altuntaş I, et al. (2008) The protective effect of erythropoietin on renal injury induced by abdominal aorticischemia-reperfusion in rats. J Surg Res 149(2): 206-213.

19. Minamishima YA, Moslehi J, Bardeesy N, Cullen D, Bronson RT, et al (2008) Somatic inactivation of the PHD2 prolyl hydroxylase causes polycythemia and congestive heart failure. Blood 111(6): 3236-3244.

20. Lee TH, Kim SU, Yu SL, Kim SH, Park DS, et al. (2003) Peroxiredoxin II is essential for sustaining life span of erythrocytes in mice. Blood 101(12): 5033-5038.

21. Ruschitzka FT, Wenger RH, Stallmach T, Quaschning T, de Wit C, et al. (2000) Nitric oxide prevents cardiovascular disease and determines survival in polyglobulic mice overexpressing erythropoietin. Proc Natl Acad Sci USA 97(21): 11609-11613.

22. Gentz EJ, Pearson EG, Lassen ED, Snyder SP, Sharpnack E (1994) Polycythemia in a llama. J Am Vet Med Assoc 204(9): 1490-1492.

23. Lappin $\mathrm{T}$ (2003) The cellular biology of erythropoietin receptors. Oncologist Suppl 1: 15-18.

24. Sasaki R, Masuda S, Nagao M (2001) Pleiotropic functions and tissuespecific expression of erythropoietin. News Physiol Sci 16: 110-113.

25. Masuda S, Kobayashi T, Chikuma M, Nagao M, Sasaki R (2000) The oviduct produces erythropoietin in an estrogen- and oxygen-dependent manner. Am J Physiol Endocrinol Metab 278(6): E1038- E1044.

26. Ochiai H, Park HM, Nakamura A, Sasaki R, Okumura JI, et al. (1998) Synthesis of human erythropoietin in vivo in the oviduct of laying hens by localized in vivo gene transfer using electroporation. Poult Sci 77(2): 299-302.
Your next submission with Juniper Publishers will reach you the below assets

- Quality Editorial service

- Swift Peer Review

- Reprints availability

- E-prints Service

- Manuscript Podcast for convenient understanding

- Global attainment for your research

- Manuscript accessibility in different formats

( Pdf, E-pub, Full Text, Audio)

- Unceasing customer service

Track the below URL for one-step submission

https://juniperpublishers.com/online-submission.php 